\title{
Bioavailability of Long Acting Capsules of Melatonin in Mexican Healthy Volunteers
}

Mireya López-Gamboa ${ }^{1 *}$, Juan Salvador Canales-Gómez ${ }^{2}$, Teresita de Jesús Castro Sandoval ${ }^{1}$, Emmanuel Núñez Tovar ${ }^{1}$, Maricela Alonso Mejía $^{1}$, María de los Ángeles Melchor Baltazar ${ }^{1}$ and José Antonio Palma-Aguirre ${ }^{1}$

${ }^{1}$ Centro de Estudios Científicosy Clínicos Pharma, S.A. de C.V., Mexico City, Mexico

${ }^{2}$ Productos Medix S.A. de C.V., Mexico City, Mexico

\begin{abstract}
Melatonin is a molecule that is essentially secreted by the pineal gland. The oral bioavailability of immediate release melatonin is low, and several pharmacokinetic parameters have a high variability in $\mathrm{C}_{\max }$ and volume of distribution.

The aim of this study was to investigate the bioavailability profile of long acting melatonin in Mexicans. Twelve healthy volunteers participated into the study. After 12 hour overnight fast, subjects received a single capsule of long acting of melatonin $5 \mathrm{mg}$ dose. For the pharmacokinetic analysis, blood samples were drawn at baseline, $0.25,0.50$, $0.75,1.0,1.25,1.5,1.75,2.0,3.0,4.0,6.0,8.0,10.0,12.0$ and 24.0 hours after dosing.

The pharmacokinetic values were $\mathrm{C}_{\max }$ of $8.768 \pm 7.043 \mathrm{ng} / \mathrm{mL}, \mathrm{T}_{\max }$ of $2.7 \pm 0.77 \mathrm{~h}, \mathrm{AUC}_{0-\mathrm{t}}$ of $29.814 \pm 24.931 \mathrm{~h} . \mathrm{ng} /$ $\mathrm{mL}, \mathrm{AUC}_{0-\infty}$ of $38.537 \pm 24.658 \mathrm{~h} . \mathrm{ng} / \mathrm{mL}$, Cl of $185.293 \pm 121.806 \mathrm{~L} / \mathrm{h}, \mathrm{Vd}$ of $451.370 \pm 510.039 \mathrm{~L}$ and $\mathrm{t}_{1 / 2}$ of $1.509 \pm 0.768$ h.

The pharmacokinetic values of long acting melatonin of our study showed a high variability in $\mathrm{C}_{\max }$, clearance, halflife time and apparent volume of distribution in Mexican volunteers, and there are consistent with the great variability reported in other populations that used the short acting melatonin.
\end{abstract}

Keywords: Melatonin; Bioavailability; human; HPLC; MS-MS; Long acting capsules

\section{Introduction}

Melatonin (N-acetyl-5-methoxytryptamine) is a small lipophile molecule that is essentially secreted by the pineal gland and its synthesis shows a circadian pattern (Weaver et al., 1993; Jung and Ahmad, 2006). The neurohormone is produced during the dark phase of the day-night cycle by the pineal gland in a wide range of species (Fourtillan et al., 2001). In addition to the pineal gland, melatonin is also synthesized in the retina, bone marrow, gastrointestinal tract, and bile. It has a several functions including regulation of the reproductive axis (Tamarkin et al., 1985; Lang, 1986; Reiter, 1991) regulation of circadian rhythms (Cassone, 1990; Weaver et al., 1993) and antioxidant activity (Reiter et al., 1994).

During the day the serum endogenous melatonin concentration is low $(10-20 \mathrm{pg} / \mathrm{mL})$, at night reach peak values $(80-150 \mathrm{pg} / \mathrm{mL})$ between midnight and 3:00 am. The half-life of melatonin in the serum is 30 to 60 minutes (Waldhauser et al., 1984; Mallo et al., 1990; Cavallo and Ritschel, 1996). In the blood, $50 \%$ to $75 \%$ of melatonin is bound reversibly to albumin and glycoproteins. Up to $60 \%$ of an oral dose has First-pass metabolism in the liver cytochrome P450 enzyme CYP1A2 (Waldhauser et al., 1984; Lane and Moss, 1985). Recently it has become evident that the pituitary hormone melatonin is quite a selective substrate for CYP1A2 (Facciolá et al., 2001; Härtter et al., 2001). Mendoza-Cantú and colleagues investigated the frequency of CYP1A2 5'-flanking region in Mexicans and they found that frequencies are higher than those previously reported for other human populations (Mendoza-Cantú et al., 2004).

The oral bioavailability of immediate release melatonin is about 3\% to $76 \%$ (Waldhauser et al., 1984; Lane and Moss, 1985). The apparent volume of distribution reported in several studies has discrepancy. Fourtillan and colleagues reported a volume of distribution at steady state of $0.99 \mathrm{~L} / \mathrm{kg}$ (Fourtillan et al., 2001), whereas Mallo and colleagues reported a volume of distribution of $35 \mathrm{~L}$ (Mallo et al.,
1990). In contrast, Goldberg and colleagues reported a very high volume of distribution of $6877+4522 \mathrm{~L}$, with a variation coefficient of $66 \%$ (Goldberg et al., 1997).

According de short half life time of melatonin, there are several studies with the immediate release formulation that shows a high variability in pharmacokinetics (PK) results (Waldhauser et al., 1984; Lane and Moss, 1985; Mallo et al., 1990; Goldberg et al., 1997; Fourtillan et al., 2001), however, a long acting formulation could reduce this variability in order to have better therapeutic response.

The aim of this study was to investigate the pharmacokinetic profile of long acting melatonin in Mexicans with special reference in comparing these pharmacokinetics parameters with other populations.

\section{Subjects and Methods}

\section{Ethical considerations}

The study protocol was approved by the ethics and research committees of the Centro de Estudios Cientificos y Clinicos Pharma S. A. de C. V. (Amores \#320; Col. Del Valle; Del. Benito Juarez; Mexico, D. F. Mexico City) in June 20, 2009, prior to trial initiation. The study was carried out in accordance with the principles of the

*Corresponding author: Mireya López-Gamboa, MD, PhD, Centro de Estudios Científicos y Clínicos Pharma, S.A. de C.V., Mexico City, Mexico, Tel: 52+ 555682 2755; Fax: 52+ 555682 2755; E-mail: mlopez@cecycpharma.com, dralopezg@gmail.com

Received May 24, 2010; Accepted September 28, 2010; Published September 30, 2010

Citation: López-Gamboa M, Canales-Gómez JS, Sandoval TJC, Tovar EN, Mejía MA, et al. (2010) Bioavailability of Long Acting Capsules of Melatonin in Mexican Healthy Volunteers. J Bioequiv Availab 2: 116-119. doi:10.4172/jbb.1000042

Copyright: (C) 2010 López-Gamboa M, et al. This is an open-access article distributed under the terms of the Creative Commons Attribution License, which permits unrestricted use, distribution, and reproduction in any medium, provided the original author and source are credited. 
Declaration of Helsinki and its amendments and the International Conference of Harmonisation Guidelines for Good Clinical Practices. Beforehand to start the study, the clinical investigator informed the subjects of all aims, methods, expected study duration, anticipated risks and discomfort it could entail, and a written informed consent was obtained from each subject.

\section{Subjects selection and clinical procedures}

Twelve healthy volunteers (six females and six males), aged between 18 and 55 years were included based on their medical history, clinical examination results, and routine laboratory tests. Subjects with HIV or hepatitis B or C virus were excluded. All healthy volunteers were selected from information's database of the Centro de Estudios Cientificos y Clinicos Pharma S. A. de C. V., Mexico City, Mexico. All eligible subjects provided written informed consent for participation in the study.

\section{Study design and clinical procedures}

A single, open-label, one sequence, single dose design was used. The subjects arrived at the clinical Unit the day before to beginning the study and they were fasted for 12 hours overnight before drug administration. A single long-acting capsule of melatonin $5 \mathrm{mg}$ (CRONOCAPS ${ }^{\circledR}$, manufactured by Productos Medix, S. A. de C. V) was given with $250 \mathrm{~mL}$ of water to each subject. Blood samples were drawn at baseline time (before drug study administration) and at 0.25 , $0.50,0.75,1.0,1.25,1.5,1.75,2.0,3.0,4.0,6.0,8.0,10.0,12.0$ and 24.0 hours after study drug administration. The blood samples $(6 \mathrm{~mL})$ were collected in the following manner: a $20-G$ catheter (Jelco ${ }^{\circledR}$ Plus, Medex Medical Ltd. Ascot, United Kingdom) was placed in a suitable forearm vein and the blood sample was drawn into a heparinized vacuum tube (Vacutainer ${ }^{\circledR}$, Becton-Dickinson and Company, Franklin Lakes, New Jersey, USA). Plasma was obtained by centrifugation (2000 $\mathrm{g}$ for 10 minutes at room temperature) and was stored frozen at $-70^{\circ} \mathrm{C}$ until it was analyzed by HPLC with MS-MS detector.

\section{Tolerability}

Tolerability was assessed by monitoring vital signs (blood pressure, heart rate, body temperature) at baseline, 4.5, 11.5 and 23.5 hours after drug administration. As well subjects were interviewed as regards the potential of adverse events (AEs) during the whole study.

\section{Determination of plasma melatonin concentrations}

Chemicals: Melatonin was donated by Productos Medix S.A. de C.V.; Venlafaxine were obtained from European Directorate for the Quality of Medicines \& Health Care. Water (HPLC grade) was obtained by System Millipore Elix 5/Milli Q; methanol (MeOH HPLC grade) and ether anhydrous, hexane and formic acid (grade reactive), were obtained from JT Baker (Xalostoc, Mecixo). Ammonium fromiate (reagent grade) was obtained from Sigma-Aldrich (St. Louis, USA).

Chromatographic conditions: The HPLC (Alliance 2690 Waters) was coupled to a mass spectrometer Quattro micro. The chromatographic conditions were: column Zorbax eclipse XDB-C18, 2.1 x $50 \mathrm{~mm}, 5$ $\mu \mathrm{m}$; ammonium formiate $5 \mathrm{mM} \mathrm{pH} 3.5 \pm 0.05: \mathrm{MeOH}(50: 50 \mathrm{v} / \mathrm{v})$ was used as mobile phase; the injection volume was $5 \mu \mathrm{L}$; the flow rate was maintained constant at $0.3 \mathrm{~mL} / \mathrm{min}$; the column temperature was $25^{\circ} \mathrm{C}$; the retention times were between 0.7 to 1.0 minutes for melatonin and between 1.0 to 1.3 minutes for venlafaxine (internal standard).

\section{Preparation of calibration standards and quality:}

- Control samples: In order to prepare stock standard solution of Melatonin, $10 \mathrm{mg}$ of melatonin was dissolved in $20 \mathrm{~mL}$ methanol-water $(50: 50, \mathrm{v} / \mathrm{v})$. The stock solution was then further diluted with methanol-water (50:50, v/v) in order to obtain the different working solutions, from which the spiked plasma samples were prepared by appropriate dilution on ranging 2.5 , 5.0, 10.0, 20.0, 40.0, 60.0, 70.0, $90.0 \mathrm{ng} / \mathrm{mL}$. Quality control samples were prepared at low $(7.5 \mathrm{ng} / \mathrm{mL})$, medium $(50.0 \mathrm{ng} /$ $\mathrm{mL})$ and high $(80.0 \mathrm{ng} / \mathrm{mL})$ concentrations in the same way as the plasma samples for calibration.

Sample preparation: The extraction method consisted in a liquidliquid extraction: Briefly, $500 \mu \mathrm{L}$ of plasma was mixed with $25 \mu \mathrm{L}$ of internal standard solution (venlafaxine, $200 \mathrm{ng} / \mathrm{mL}$ ), $75 \mu \mathrm{L}$ methanolwater $(50: 50, v / v)$, and $4 \mathrm{~mL}$ of anhydro-hexane ether $(80: 20 \mathrm{v} / \mathrm{v})$ was added. After vortexing $(2 \mathrm{~min})$ and centrifugation $(1160 \mathrm{xg}, 5 \mathrm{~min})$ the aqueous phase was freeze 10 minutes at $-70^{\circ} \mathrm{C}$; the organic phase was evaporated to dryness and the residue was dissolved in $10 \mathrm{~mL}$ of mobile phase.

\section{Pharmacokinetics and statistical analysis}

The pharmacokinetics analysis was Individual plasma concentration-time curves were constructed; $\mathrm{C}_{\max }$ and $\mathrm{T}_{\max }$ were directly obtained from the curve. AUC from time 0 (baseline) to 24 hours $\left(\mathrm{AUC}_{0-24}\right)$ was calculated using the trapezoidal rule. From the terminal log-decay phase, elimination rate constant (ke) was estimated using linear regression, and $t_{1 / 2}$ was estimated using the following equation:

$$
\mathrm{t}_{1 / 2}=\ln 2 / \mathrm{ke}
$$

where In was defined as the natural log; and extrapolation of AUC from baseline to infinity $\left(\mathrm{AUC}_{0-\infty}\right)$ was calculated as follows:

$$
\mathrm{AUC}_{0-\infty}=\mathrm{AUC}_{0-24}+\left(\mathrm{C}_{24} / \mathrm{ke}\right)
$$

where $C_{24}$ was defined as concentration at 24 hours.

\section{Results}

A total of 12 subjects were enrolled in the study. Subjects had the following characteristics: age range 21 to 46 years, mean weight of $64.5 \mathrm{~kg}$, and mean height of $1.7 \mathrm{~m}$ (Table 1).

\section{Safety}

Some adverse effects occurred in the volunteers during the study after melatonin administration of a $5 \mathrm{mg}$ long acting capsule as follows: one volunteer had mild headache one hour post-dose, other volunteer had mild headache 3 hours post-dose, and the last one had mild headache 7 hours post-dose. All adverse reactions disappeared spontaneously without drug medication. These adverse events were classified with probable association with the study drug.

Mild somnolence occurred in all volunteers, but it was not considered as an adverse event, because just is the therapeutic effect of melatonin.

\section{Pharmacokinetic parameters}

Mean and SD values of $\mathrm{C}_{\max }, \mathrm{T}_{\max }, \mathrm{t}_{1 / 2}, \mathrm{AUC}_{0-\mathrm{t}}, \mathrm{AUC}_{0-\infty}, \mathrm{Cl}$ (clearance) and $\mathrm{Vd}$ (apparent volume of distribution) are shown in table 2.

\begin{tabular}{|c|c|c|c|c|}
\hline $\begin{array}{c}\text { Demographic } \\
\text { characteristics }\end{array}$ & Mean & $\begin{array}{c}\text { Standard } \\
\text { Deviation }\end{array}$ & C. V.\% & Min -Max \\
\hline Age (years) & 29.333 & 8.804 & 30.015 & $20.0-46.0$ \\
\hline Weight (Kg) & 64.508 & 5.824 & 9.028 & $55.9-72.5$ \\
\hline height (m) & 1.674 & 0.080 & 4.788 & $1.55-1.79$ \\
\hline BMl & 23.024 & 1.560 & 6.776 & $20.92-25.86$ \\
\hline
\end{tabular}

Table 1: Descriptive statistics of demographic characteristics of the volunteers: $n$ $=12$. 


\begin{tabular}{|c|c|c|c|}
\hline Number Volunteer & $\mathbf{t}_{\mathbf{1 / 2}}(\mathbf{h})$ & $\mathbf{V d}(\mathbf{L})$ & $\mathbf{C l}(\mathbf{L} / \mathbf{h})$ \\
\hline 1 & 1.29 & 502.56 & 270.43 \\
\hline 2 & $\mathrm{ND}$ & $\mathrm{ND}$ & $\mathrm{ND}$ \\
\hline 3 & 1.06 & 387.66 & 252.67 \\
\hline 4 & $\mathrm{ND}$ & $\mathrm{ND}$ & $\mathrm{ND}$ \\
\hline 5 & 2.72 & 1755.02 & 448.10 \\
\hline 6 & 0.92 & 71.58 & 54.05 \\
\hline 7 & $\mathrm{ND}$ & $\mathrm{ND}$ & $\mathrm{ND}$ \\
\hline 8 & 0.94 & 179.78 & 132.17 \\
\hline 9 & 1.03 & 268.42 & 180.78 \\
\hline 10 & 1.24 & 224.36 & 125.11 \\
\hline 11 & 2.94 & 487.36 & 114.97 \\
\hline 12 & 1.44 & 185.59 & 89.36 \\
\hline Mean & $\mathbf{1 . 5 1}$ & $\mathbf{4 5 1 . 3 7}$ & $\mathbf{1 8 5 . 2 9}$ \\
\hline Standard deviation & $\mathbf{0 . 7 7}$ & $\mathbf{5 1 0 . 0 4}$ & $\mathbf{1 2 1 . 8 1}$ \\
\hline Minimum & $\mathbf{0 . 9 2}$ & $\mathbf{7 1 . 5 8}$ & $\mathbf{5 4 . 0 5}$ \\
\hline Maximum & $\mathbf{2 . 9 4}$ & $\mathbf{1 7 5 5 . 0 2}$ & $\mathbf{4 4 8 . 1 0}$ \\
\hline CV\% & $\mathbf{5 0 . 9 2}$ & $\mathbf{1 1 3 . 0 0}$ & $\mathbf{6 5 . 7 4}$ \\
\hline
\end{tabular}

Table 2: Individual melatonine pharmacokinetic parameters after $5 \mathbf{~ m g}$ administration in Mexican healthy volunteers. (ND. Not determined, due to lack of characterisation of the elimination phase).

\begin{tabular}{|c|c|c|c|}
\hline Pharmacokinetic parameter & Mean & Standard deviation & CV\% \\
\hline $\mathrm{C}_{\max }(\mathrm{ng} / \mathrm{mL})$ & 8.77 & 7.04 & 80.33 \\
\hline $\mathrm{AUC}_{0-\mathrm{t}}(\mathrm{hr} . \mathrm{ng} / \mathrm{mL})$ & 29.81 & 24.93 & 83.62 \\
\hline $\mathrm{AUC}_{0-\mathrm{Inf}}(\mathrm{hr} . \mathrm{ng} / \mathrm{mL})$ & 38.54 & 24.66 & 63.98 \\
\hline $\mathrm{t}_{\max }(\mathrm{hr})$ & 2.79 & 0.78 & 27.76 \\
\hline $\mathrm{t}_{1 / 2}(\mathrm{hr})$ & 1.51 & 0.77 & 50.91 \\
\hline $\mathrm{Vd}(\mathrm{L})$ & 451.37 & 510.04 & 113.00 \\
\hline $\mathrm{Cl}(\mathrm{L} / \mathrm{hr})$ & 185.29 & 121.81 & 65.74 \\
\hline
\end{tabular}

Table 3: Pharmacokinetics parameters of long-acting capsules of melatonin $(n=12)$

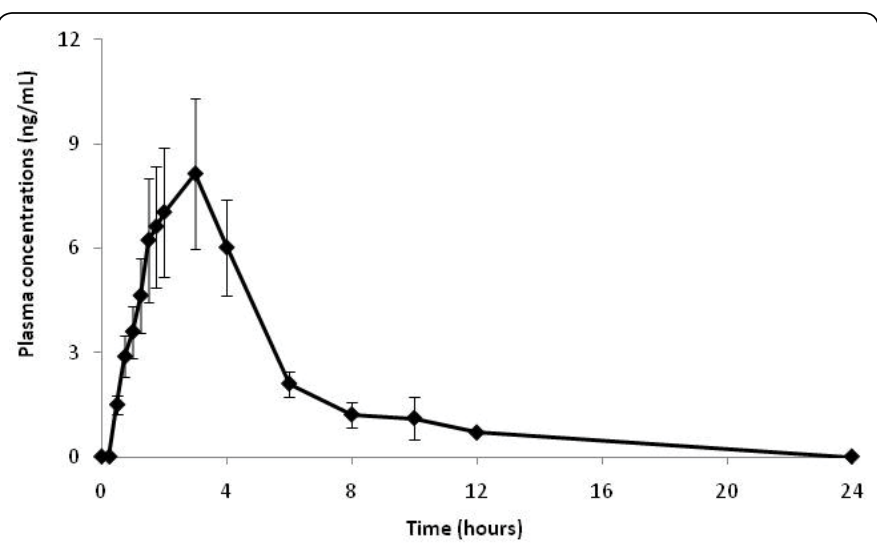

Figure 1: Plasma profile of $5 \mathrm{mg}$ long acting capsule's melatonin (mean \pm standard error).

Pharmacokinetic values were $\mathrm{C}_{\max }$ of $8.768 \pm 7.043 \mathrm{ng} / \mathrm{mL}, \mathrm{T}_{\max }$ of $2.7 \pm 0.77 \mathrm{~h}, \mathrm{AUC}_{0 \mathrm{t}}$ of $29.814 \pm 24.931 \mathrm{hr} . \mathrm{ng} / \mathrm{mL}, \mathrm{AUC}_{0-\infty}$ of 38.537 $\pm 24.658 \mathrm{hr} . \mathrm{ng} / \mathrm{mL}, \mathrm{Cl}$ of $185.293 \pm 121.806 \mathrm{~L} / \mathrm{h}, \mathrm{Vd}$ of $451.370 \pm$ $510.039 \mathrm{~L}$ and $t_{1 / 2}$ of $1.509 \pm 0.768 \mathrm{~h}$ (Table 3). Figure 1 shows the mean of plasma melatonin concentrations after drug administration.

\section{Discussion}

The pharmacokinetic values of long acting melatonin of our study showed a high variability in $\mathrm{C}_{\max }$, clearance, half-life and apparent volume of distribution in Mexican volunteers, and there are consistent with the great variability reported in other populations that used the short acting melatonin.

After the oral administration of melatonin $5 \mathrm{mg}$ dissolved in vehicle solution, Goldberg and colleagues (Goldberg et al., 1997) reported values of $\mathrm{T}_{\max }$ of $0.5 \pm 0.18 \mathrm{~h}$, half life time of $0.91 \pm 0.15$ $\mathrm{h}$, clearance of $5160 \pm 3351 \mathrm{~L} / \mathrm{h}$, and volume of distribution of 6877 $+4522 \mathrm{~L}$. Melatonin has very large apparent volume of distribution and clearance values which implies a high first-pass metabolism and low oral bioavailability.

In the other hand, Fourtillan and colleagues (Fourtillan et al., 2000) reported pharmacokinetic parameters after oral administration of $5 \mathrm{mg}$ of melatonin near three-fold greater in female subjects than in males, with large inter-individual variations. The mean of maximum plasma melatonin concentration $\mathrm{C}_{\max }$ was found at $243.7 \pm$ $124.6 \mathrm{pg} / \mathrm{mL}$ and $623.6+/-575.1 \mathrm{pg} / \mathrm{mL}$ for male and female subjects respectively, while the mean values for AUCs were $236 \pm 107 \mathrm{pg} . \mathrm{h} /$ $\mathrm{mL}$ and $701 \pm 645 \mathrm{pg} . \mathrm{h} / \mathrm{mL}$. The absolute bioavailability of melatonin was from 1 to $37 \%$ : mean was of $8.6 \pm 3.9 \%$ and $16.8 \pm 12.7 \%$ for male and female subjects, respectively. In our study we did not observe any gender differences.

De Muro and colleagues (DeMuro et al., 2000) reported that after oral melatonin tablets in doses of 2 and $4 \mathrm{mg}$ showed poor absolute bioavailability, either due to poor oral absorption, large first-pass metabolism, or a combination of both. They assume that a saturation of first-pass metabolism probably occurs.

Racial and ethnic differences in drug-metabolizing ability associated with genetic or cultural/environmental factors are not only well recognized but also important in understanding interindividual variability in drug responsiveness. There are reports about the pharmacokinetics of melatonin of oral and intravenous administrations (Waldhauser et al., 1984; Vakkuri et al., 1985; Mallo et al., 1990; DeMuro et al., 2000). Waldhauser and colleagues] reported an elimination half-life of $0.80 \mathrm{~h}$ after oral administration of crystalline melatonin (80 mg) in gelatin capsules (Waldhauser et al., 1984). Lane and Moss reported a prominent first pass hepatic metabolism and reduced bioavailability for orally administered melatonin (Lane and Moss, 1985). Using clearance parameters, endogenous production rates for melatonin were determined for normal individuals and patients with cirrhosis. Normal melatonin production was 28.8 micrograms/day, while the production rate for cirrhotic patients was 12.3 micrograms/day, suggesting also a decrease in daily melatonin production.

In our study, $\mathrm{C}_{\max }$ values were different to other publications. Goldberg and coworkers (Goldberg et al., 1997) reported a $C_{\max }$ value of $1841 \pm 2316 \mathrm{pg} / \mathrm{mL}$ with a a CV of $126 \%$, whereas in our study we have a $C_{\max }$ value of $8.768 \pm 7.043 \mathrm{ng} / \mathrm{mL}$, with a $\mathrm{CV}$ of $80 \%$. In our study, the apparent volume of distribution was of $451 \pm 510 \mathrm{~L}$, with a very high coefficient of variation (CV) of $112 \%$. This result is totally different than those published in diverse populations (Mallo et al., 1990; Goldberg et al., 1997; Fourtillan et al., 2001). These results in $\mathrm{C}_{\max }$ and $\mathrm{Vd}$ are probably due to several factors, with special emphasis in the long acting formulation of melatonin used in our study and the CYP1A2 activity of our Mexican volunteers. Further clinical studies should be necessary in order to evaluate the therapeutic utility of his long-acting melatonin formulation.

\section{Acknowledgements}

The study was supported entirely by Laboratories Productos Medix S. A. de C. V., Mexico City, Mexico.

\section{Conflict of Interest Statement}

All the authors declare that we have not conflict of interest with the publication of this manuscript. 
Citation: López-Gamboa M, Canales-Gómez JS, Sandoval TJC, Tovar EN, Mejía MA, et al. (2010) Bioavailability of Long Acting Capsules of Melatonin in Mexican Healthy Volunteers. J Bioequiv Availab 2: 116-119. doi:10.4172/jbb.1000042

\section{References}

1. Bechgaard E, Lindhardt K, Martinsen L (1998) High-performance liquid chromatographic analysis of melatonin in human plasma and rabbit serum with on-line column enrichment. J Chromatogr B Biomed Sci Appl 712: 177-181.

2. Cassone VM (1990) Effects of melatonin on vertebrate circadian systems. Trends Neurosci 13: 457-464.

3. Cavallo A, Ritschel WA (1996) Pharmacokinetics of melatonin in human sexual maturation. J Clin Endocrinol Metabol 81: 1882-1886.

4. DeMuro RL, Nafziger AN, Blask DE, Menhinick AM, Bertino JS Jr (2000) The absolute bioavailability of oral melatonin. J Clin Pharmacol 40: 781-784.

5. Facciolá G, Hidestrand M, von Bahr C, Tybring G (2001) Cytochrome P450 isoforms involved in melatonin metabolism in human liver microsomes. Eur $\mathrm{J}$ Clin Pharmacol 56: 881-888.

6. Fourtillan JB, Brisson AM, Fourtillan M, Ingrand I, Decourt JP, et al. (2001) Melatonin secretion occurs at a constant rate in both young and older men and women. Am J Physiol Endocrinol Metab 280: E11-E22.

7. Fourtillan JB, Brisson AM, Gobin P, Ingrand I, Decourt JP (2000) Bioavailability of melatonin in humans after day-time administration of $\mathrm{D}(7)$ melatonin. Biopharm Drug Dispos 21: 15-22.

8. Goldberg MJ, Bergstrom RF, Smith BP, Simcox EA, Thomasson HR, et al. (1997) Melatonin: Pharmacokinetics and effect on body temperature in men. Sleep Research 26: 101.

9. Härtter S, Ursing C, Morita S, Tybring G, von Bahr C, et al. (2001) Orally given melatonin may serve as a probe drug for cytochrome P450 1A2 activity in vivo: a pilot study. Clin Pharmacol Ther 70: 10-16.

10. Jung B, Ahmad N (2006) Melatonin in Cancer Management: Progress and Promise. Cancer Res 66: 9789-9793.
11. Lane EA, Moss HB (1985) Pharmacokinetics of melatonin in man: first pass hepatic metabolism. J Clin Endocrinol Metab 61: 1214-1216.

12. Lang U (1986) Melatonin and puberty. In: Reiter RJ, ed. lineal research reviews. New York: Liss. vol4: 199-243.

13. Mallo C, Zaĭdan R, Galy G, Vermeulen E, Brun J, et al. (1990) Pharmacokinetics of melatonin in man after intravenous infusion and bolus injection. Eur $\mathrm{J}$ Clin Pharmacol 38: 297-301.

14. Mendoza-Cantú A, Castorena-Torres F, Bermudez M, Martínez-Hernández $R$, Ortega A, et al. (2004) Genotype and allele frequencies of polymorphic cytochromes P450 CYP1A2 and CYP2E1 in Mexicans. Cell Biochem Funct 22: 29-34.

15. Reiter RJ (1991) Pineal gland: interface between the photoperiodic environment and the endocrine system. Trends Endocrinol Metab 2: 13-19.

16. Reiter RJ, Tan DX, Poeggeler B, Menendez-Pelaez A, Chen LD, et al. (1994) Melatonin as a free radical scavenger: implications for aging and age-related diseases. Ann N Y Acad Sci 719: 1-12.

17. Tamarkin L, Baird CJ, Almeida OF (1985) Melatonin: a coordinating signal for mammalian reproduction? Science 227: 714-720.

18. Vakkuri O, Leppäluoto J, Kauppila A (1985) Oral administration and distribution of melatonin in human serum, saliva and urine. Life Sci 37: 489-495.

19. Waldhauser F, Waldhauser M, Lieberman HR, Deng MH, Lynch HJ, et al. (1984) Bioavailability of oral melatonin in humans. Neuroendocrinology 39: 307-13.

20. Weaver DR, Stehle JH, Stopa EG, Reppert SM (1993) Melatonin receptors in human hypothalamus and pituitary: implications for circadian and reproductive responses to melatonin. J Clin Endocrinol Metab 76: 295-301. 